\title{
English legalese translation into Indonesian
}

\author{
HARU DELIANA DEWI, ANDIKA WiJAYA, \\ AND RAHAYU S. HIDAYAT
}

\begin{abstract}
One of the difficulties in translating English legal texts derives from the uses of specialized language, also known as "legalese". This research is a preliminary study which sets out to investigate the translation of English legalese into Indonesian in four open-accessed agreements. The data in English, which cover terms and expressions commonly used in legal documents, are classified into seven categories of legal English features. Their Indonesian translations are analysed by using Indonesian dictionaries to discover whether they can be considered as Indonesian legal language. The research finds that most English legalese terms and expressions studied are translated using common words and expressions, which can be looked up in the official monolingual Indonesian dictionary (Kamus Besar Bahasa Indonesia/KBBI) but cannot be found in an Indonesian law dictionary. Therefore, it is concluded that Indonesian legal language is not yet established.
\end{abstract}

KEYWORDS

English legalese; legal documents; legal language; Indonesian translation; terms; expressions.

\section{INTRODUCTION}

Legal documents have always been among the most difficult texts to translate. In addition to the different legal systems of the source and target cultures, the specialized language used in most legal documents also contributes to the difficulty faced by translators of such texts. Even though there have been some movements towards using plain language in drafting contracts, many contracts are still written in a distinctive style which characterizes the traditional legal texts. Other than the frequent uses of long and very complex sentences, many contracts use various terms which are rarely used in daily communication settings. This paper sets out to investigate whether such words or phrases in

The authors can be reached at: harudd.dewi7@gmail.com (HARU DELIANA DEWI), andika. wijaya@ui.ac.id (ANDIKA WIJAYA), and rahayu.surtiati@gmail.com (RAHAYU S. HIDAYAT). More information about the authors can be found at the end of the article.

(C) 2020 Faculty of Humanities, Universitas Indonesia

H.D. DEWI, A. WIJAYA, AND R.S. HIDAYAT | DOI: 10.17510/wacana.v21i3.866. 
contracts, which have become distinct features of legal English, are translated using language items which can also be considered distinct features of legal language in Indonesian.

Studies on Indonesian legal translations, particularly those which focus on the translation of words and phrases, are still scarce. Previous studies on Indonesian translation of legal documents have tended to focus on the translation methods, techniques or strategies employed by the translators (Aris Wuryantoro, D. Edi Subroto, and Mangatur Nababan 2014; Hanifa Pascarina, Mangatur Nababan, and Riyadi Santosa 2017). Meanwhile, the study conducted by Ade I. Khairani (2008) on the Indonesian translations of employment contracts focuses on the syntactical shifts in the translations. Finally, overlapping very much with this study, a thesis written by Endang D. Hastuti (2007) discusses the analysis the Indonesian translation of English legal terms. However, unlike this study which concentrates on the translation of terms and conditions in legal agreements, this earlier study focuses on a law textbook on intellectual property rights. The study itself found that the translator of the book managed to find the Indonesian equivalents of some terms used in the book and employed phonological translations for these without giving an Indonesian counterpart. Nonetheless, it can be argued that the main purpose of the result of the study itself is to convey information to their readers, while other legal documents such as acts of legislation and contracts are performative texts (Lorenzo Fiorito 2006), whose main purposes include setting out the rights and obligations of the parties involved.

This research serves as a preliminary study to identify the existence of legal language features, particularly related to the lexical features, in the Indonesian translations of English legal documents. This study is also expected to be used as the foundation for many future projects, such as the compilation of an English-Indonesian legal glossary or dictionary, training design for Indonesian legal translators, and future research projects in the fields of translation studies and terminology related to legalese. This paper will be presented in the following format. After identifying the research gaps from previous research and setting out the purpose of this research, the paper will discuss the features of legal language in both the English and Indonesian languages. In the next section, the paper will outline the method applied in this research. The paper will then discuss the findings of the research. Finally, the paper will present the conclusion made from the discussion in the previous section.

\section{LEGALESE AND LEGAL DOCUMENTS}

According to Black's law dictionary (Bryan A. Garner and Henry C. Black 2004), eighth edition, the term "legalese" refers to "the jargon characteristically used by lawyers, esp. in legal documents" (Garner and Black 2004: 2848). Such documents, according to Deborah Cao (2007), share some distinctive linguistic features which can be further classified into textual, syntactical, and lexical categories. The textual features of legal documents are the common parts which can be found in almost every kind of such documents, such as the definition, 
governing law and force majeure clauses in contracts and agreements (Cao 2007: 85). Meanwhile, long and complex sentences, verb nominalizations, and impersonal language style resulting from the peculiar use of passive voice and pronouns are among the syntactic features of legal documents written in English (Cao 2007; Ina Verentina-Chiriac 2012). Last but not least, the lexical features, or the features related to words and phrases, which are prominent in legal documents written in English, consist of archaisms, formal vocabulary, technical languages, synonymy, foreign words of Latin or French origin, and modal auxiliaries (Cao 2007; Verentina-Chiriac 2012; Chen Yan and Yun Dai 2014).

This research focuses on the Indonesian translation of specialized words, terms or phrases in English agreements. Therefore, the "legalese" features which are not directly related to such language items, including syntactic and textual features, will not be explored in more depth in this research. In contrast, lexical features will be used as a reference to categorize the language items in the source text and to see whether similar features exist in the Indonesian translation. The section below will briefly outline the lexical features of legal English and the features of Indonesian legal language.

\subsection{ARCHAISMS}

These refer to words and terms which have become obscure over the years since other terms with similar meanings have come to be used more frequently. Examples of archaisms are: "hereinafter", "arraign", "surrejoinder", "aforesaid", and some formal expressions which are often used by lawyers, such as "pursuant to", "prior to", and "subsequent to" (Verentina-Chiriac 2012: 104).

\subsection{ForMAL VOCABULARY}

Legal texts tend to use formal words or phrases, rather than their more casual alternatives, to establish authority (Chen and Yun 2014: 2). For example, the phrase "because of" is less likely to be found in legal texts compared to its formal synonyms "due to" and "by virtue of". Many contracts in English also tend to use the word "commence" and "terminate" instead of "start" and "end".

\subsection{TECHNICAL TERMS}

Technical terms might refer to purely legal terms, legal jargon and common words which have specialized meanings when they are used in an English legal context. Examples of pure legal terms are "tort", "patent", "bailment", and "abatement'. Meanwhile, legal jargon refers to the terms which are often used among lawyers to facilitate communications, such as "pro tem", "boilerplate case", "punies" (from 'punitive damages'), and "depo" (from 'deposition'). Finally, there are polysemous words, such as "attachment", "action", and "furnish", whose meanings can be different from their general meanings when they are used in legal documents (Verentina-Chiriac 2012: 104). 


\subsection{FOREIGN WORDS}

These words refer to the words of Latin and French origin frequently used in legal English, either transliterated (for example, "adjacent", "verdict", "counsel") or borrowed directly (for example, caveat emptor, obiter dictum, pro se) (Cao 2007: 56; Verentina-Chiriac 2012: 104). The influence of the French language on legal English is also reflected in the use of suffix "-ee" to denote the party who becomes the object of an action (for example: "lessee", "pledgee", "payee").

\subsection{WORD STRINGS AND SYNONYMY}

Verentina-Chiriac (2012) indicates that legislators might frequently use pairs or strings of synonyms on account of the uncertainty about whether the words have the exact same meaning, especially if they come from different language roots; therefore, it is safest to use each of the alternatives at the same time. Despite their apparent similarity, many lawyers believe that they are never identical as their connotational value might be slightly different (Peter Tiersma 1999 in S. Goźdź-Roszkowski 2013). Such a subtle difference may be exploited in a case or a contract, so it is sometimes necessary to use the near synonymous words altogether to prevent any loophole. Examples of these words are "legal and valid" and "over and above". Alliteration is also common, such as in the phrase "rest, residue, and remainder" (Verentina-Chiriac 2012: 104-105). This linguistic feature might originally have been used to cover all possible situations which have not perhaps been adequately included in the meaning of one single alternative, but it can present some challenges to translators since there might not be a similar string of words or synonyms with equal meanings in the target language (Cao 2007: 89-90).

\subsection{Modal AuXILIARIES}

Another type of word use which has become a distinctive characteristic of English legal texts is modal auxiliary. Klaudia Bernadrova-Gibová (2011) found that "shall" and "may" are the most frequent modals used in European Union legal texts written in English. Translators of different languages might face some challenges in translating the modal "shall" as it can have either performative or prescriptive meanings in addition to expressing futurity as it is usually used in common speech (Bernadrova-Gibová 2011; Chen and Yun 2014). Since the rise of the plain language use in legal settings, the use of the modal "shall" has been limited to talk about obligations, and it has been even suggested to replace this word with the modal "must". However, this has not always been the case, as the modal "shall" can be interpreted as 'may', 'will', or 'must' in traditional legal language, which has sparked many debates among researchers and lawyers over decades (Olga Krapivkina 2017; Bruce Corsino 2020). In some languages, including Indonesian, each of the possible meanings is expressed by different words. 


\subsection{FIXED EXPRESSIONS}

In addition to the classifications of words and phrases discussed in different previous works above, we also found that there are certain expressions which are common in English legal texts but not so common in other types of texts. An example of these expressions would be the phrases identified by Cao (2007: 94) as the common phrases to introduce a proviso (for examples "provided that", "provided further that", and "subject to"). Other examples of these common expressions in the contracts are the phrases "in the event" and "including but not limited to". As such expressions have not been quite covered or put into any category in the previous works, we decided to put them into another category, which we called "fixed expressions".

\subsection{FeAtures of INDONESIAN LEGAL LANGUAGE}

The Symposium of Indonesian Language and Law held in Medan in 1974 stipulated that Bahasa Hukum Indonesia, or 'Indonesian legal language', is "a [specialized] Indonesian language used in the field of law which has its own distinctive characteristics considering its function" (Nurul Qamar and Hardianto Djanggih 2017: 340). This means that, similar to legal English, Indonesian legal language is also a variation of the more standard or widely used Indonesian language.

In terms of legal language characteristics, Harkristuti Harkrisnowo (2007) argues that there is a tendency among Indonesian legal practitioners to:

1) use long, complex sentences to explain or define something,

2) use specialized terms without any further explanation,

3) use ambiguous or homonymous terms,

4) use foreign words which do not have direct equivalents in Indonesian,

5) avoid shifting from the currently existing template (such as in the case of notarial deed).

Concerning the use of foreign words in legal settings, in contrast to legal English which often uses words of Latin and French origin, Indonesian legal language has commonly borrowed some words from Dutch. In fact, there have been bilingual Dutch-Indonesian legal dictionaries such as Istilah-istilah hukum bahasa Belanda (Paulus M. Dwidjodarmo 1973), Nederlands-Indonesisch juridisch woordenboek (Marjanne Termorshuizen-Arts 1999) and IndonesischNederlands woordenboek privaatrecht; Verbintenissenrecht (Ab Massier and Marjanne Termorshuizen-Arts 2000). This is because most of the Indonesian laws have originated from the Dutch colonial law. Nevertheless, this paper will not discuss the use of Dutch words in Indonesian legal language, as it focuses on the translation English legalese in Indonesian contracts. Furthermore, Indonesian contracts today no longer employ the use of Dutch language, or any other foreign language, since the Article 31 Paragraph (1) of the Law of the Republic of Indonesia No. 24/2009 requires any contract involving Indonesian parties to be written in Indonesian language. 
In her study on the use of legal language in Indonesian contracts, Sri $\mathrm{H}$. Wijayanti (2009) finds that many Indonesian contracts share the following common features:

1) Unusual spellings and use of punctuation,

2) Repetitive use of plural noun forms,

3) Synonymy,

4) The use of word bahwa, 'whereas' or 'that' in front of a subject,

5) The use of word forms which are not parallel,

6) Long sentences,

7) The use of expressions Dalam hal ... maka ... , 'in the event ... therefore ...'.

These features, however, are also frequently criticized since they indicate that there are still some ineffective or incorrect uses of Indonesian language in Indonesian contracts.

It is also interesting to note that the official monolingual great dictionary of Indonesian language (KBBI) puts a Huk [Hukum 'law'] label on some entries. The "Huk label" in KBBI is equivalent to the "law" label in many monolingual English dictionaries. However, this application has been inconsistent. For example, some purely legal terms, such as pidana, 'criminal law' and perdata, 'civil law', carry such a label, while others, such as wanprestasi, 'breach of contract' and terdakwa, 'defendant' do not. The same is also true for polysemous words. Some of these words, such as hak, 'right' and kewajiban, 'obligation', have been accorded the $H u k$ label to indicate their specific meaning in the field of law. In contrast, there is no Huk label on other polysemous words, such as beracara, 'having an event' or 'taking a legal action in a court', ayat, 'verse (in scriptures)' or 'paragraph (in legal documents)', and kelalaian, 'negligence', although one of the explanations of those entries has a specific meaning that is only used in the field of law.

\section{METHOD}

The data sources of this paper are legal documents which are usually and mostly confidential and cannot be accessed freely. Therefore, the data were obtained from open-accessed websites on which the legal documents have intentionally been provided for public scrutiny. This was done in order to avoid any problems with confidentiality and copyrights. Four such legal documents focusing on terms and conditions were acquired. Table 1 shows the details of the data sources. All those documents shown in Table 1 are bilingual, in English and Indonesian. They are about terms and conditions; therefore, similar legal terms and expressions are to be found in those documents. 


\begin{tabular}{|l|l|l|}
\hline Names of the documents & \multicolumn{1}{|c|}{ The link } & \multicolumn{1}{|c|}{ Short names } \\
\hline $\begin{array}{l}\text { Global Purchasing GTCS } \\
\text { Unilever: General Terms } \\
\text { and Conditions for the } \\
\text { Purchase of the Products } \\
\text { and services }\end{array}$ & $\begin{array}{l}\text { https://www/unilever.com/ } \\
\text { Images/2018-01-global-purchasing- } \\
\text { gtcs-english-indonesian_tcm244- } \\
\text { 481206_en.pdf }\end{array}$ & Document A \\
\hline $\begin{array}{l}\text { P.T. Apple Indonesia: } \\
\text { Purchase Agreement, } \\
\text { Purchase Order Terms } \\
\text { and Conditions }\end{array}$ & $\begin{array}{l}\text { https://www.apple.com/legal/ } \\
\text { procurement/docs/IND_TERMS_ } \\
\text { COND-0197.pdf }\end{array}$ & Document B \\
\hline $\begin{array}{l}\text { Purchase Order Standard } \\
\text { Terms and Conditions of } \\
\text { Mead Johnson }\end{array}$ & $\begin{array}{l}\text { https://www.meadjohnson. } \\
\text { com/sites/corp/files/Purchase_- } \\
\text { Order_Standard_Terms_and_- } \\
\text { Conditions_\%28indonesia\%29.pdf }\end{array}$ & Document C \\
\hline $\begin{array}{l}\text { Hirose Financial MY } \\
\text { LTD: Business Terms and } \\
\text { Conditions }\end{array}$ & $\begin{array}{l}\text { https://hiroseuk.com/id/pdf/ } \\
\text { terms_and_conditions_id.pdf }\end{array}$ & Document D \\
\hline
\end{tabular}

Table 1. Data sources.

From the many legal terms and expressions discovered in each document, only seventeen are found in all four documents and two in three documents. Therefore, the total number of terms and expressions discussed is nineteen. The details of all the data can be seen in the Appendices. This paper has applied a qualitative descriptive method by comparing the English version of the agreements with the Indonesian version. The results have been categorized based on the types of legalese terms and expressions explained in the literature review, and the meaning of each term and expression was looked up in an online legal dictionary called TransLegal (The World Law Dictionary Project, https:/ / www.translegal.com/legal-english-dictionary). We also used Bloomsbury's Dictionary of Law (Peter H. Collins 2004), Oxford Dictionary of Law (Jonathan Law and Elizabeth A. Martin 2009), and https://www. merriam-webster.com/dictionary to support the definitions or meanings from TransLegal. Furthermore, the results were listed and analysed based on their translation into Indonesian, and the meaning of the Indonesian terms and expressions was looked up in Kamus Besar Bahasa Indonesia (KBBI) online and The online Indonesian law dictionary (https:/ / kamushukum.web.id/). The following section displays the results of the data analysis.

\section{RESULTS AND DISCUSSION}

From the data analysis, nineteen legalese terms and expressions discovered are categorized into six, not seven, types of legalese types as we have not found foreign words used in all the documents researched. Table 2 lists the results based on the types of legalese. 


\begin{tabular}{|r|l|l|}
\hline & \multicolumn{1}{|c|}{ Type } & \multicolumn{1}{c|}{ Result } \\
\hline 1. & Synonymy & terms and conditions; any and all \\
\hline 2. & Modal auxiliary & shall; may \\
\hline 3. & Technical terms & $\begin{array}{l}\text { party/parties, apply/applicable; liability/liabilities; } \\
\text { binding; prevail }\end{array}$ \\
\hline 4. & Formal language & expressly; deemed; termination; otherwise; compliance \\
\hline 5. & Archaic words & pursuant to; hereby; notwithstanding \\
\hline 6. & Fixed expression & $\begin{array}{l}\text { in the event; including but not limited to/including and } \\
\text { without limitation }\end{array}$ \\
\hline
\end{tabular}

Table 2. Types of legalese terms and expressions.

The analysis revealed that several terms have been translated consistently, while for many others this is not the case, as discussed in detail in the following section.

\subsection{CONSISTENTLY TRANSLATED TERMS}

Out of the nineteen data items, six terms have been translated consistently into Indonesian (see Appendix 1). The first one is the term "party/parties". According to TransLegal, the word "party" refers to 'a person taking part in a business transaction, negotiating a contract bound by a contract, etc.'. It is translated consistently as pihak in Indonesian and the word pihak, according to KBBI, has several definitions. The definition related to a person is someone who belongs to a party or a group in a war, game, politics, agreement, et cetera. Therefore, "party" and pihak are synonymous, and they both belong to technical terms, as they have their own meaning in legal documents, which is different from the meaning in other types of documents. However, the word pihak is not found in The online Indonesian law dictionary, which leads to an assumption that this word in Indonesian is a common word, used in general or any topics, not limited to law.

The second term refers to "apply" and "applicable". These two words are actually from different word classes. The word "apply" is a verb, while the word "applicable" is an adjective. "Apply", according to TransLegal, is 'to have a connection with or to be relevant to somebody or something; to put something (e.g. a law) into operation'. "Applicable" refers to 'relevant to, suitable for or affecting a particular situation, thing, person, or group of people'. Both of these two words are consistently translated in Indonesian into berlaku. This word is a verb and, according to KBBI, it has several definitions: a) 'still going on' or 'lasting'; b) 'doing' or 'acting'; c) 'carrying out a duty'; d) 'can be used'; e) 'applied to'. The last definition is the most suitable meaning in the English version. Similarly, in The online Indonesian law dictionary, the definition of berlaku refers to when any laws and regulations become effective or when they are in effect. The two English words belong to technical terms in legalese as they have a different meaning when used outside legal documents, 
while in Indonesian language the word berlaku has the same meaning whether it is in legal documents or not, and in KBBI this word is not labelled Huk.

The third term refers to the word "binding" (such as in "business agreements", intended to be legally binding), which is an adjective word. According to TransLegal, this word 'requires that any party to an agreement, or any party to whom the ruling or law et cetera, is directed to obey the terms of that agreement, ruling or law et cetera'. This word is translated consistently in Documents A, B, C, and D as mengikat. Based on KBBI, this word has several meanings, as it is a common word in Indonesian, but among these definitions there is one which is related to law: " $3 . \mathrm{v}$ wajib ditepati: perjanjian yang perjanjian yang mengharuskan kedua belah pihak menepatinya dengan sungguh-sungguh". This definition refers to 'promise', to faithfully observe an agreement, or to enter into an agreement, yet it is not labelled Huk. Moreover, in The online Indonesian law dictionary, mengikat cannot be found, yet the word "binding" is found in this dictionary with the definition: mengikat dari segi hukum, 'legally binding'. These two words ("binding" and mengikat) are both legal terms belonging to technical terms, having their own meaning in legal documents.

The next word translated consistently is the word "deemed". This word is from a verb "deem", but in legal documents it is always in a past participle form "deemed". According to TransLegal, the verb "deem" means "to judge or have as an opinion'. This word, in its past participle form, is translated as dianggap and, based on KBBI, it refers to 'be considered' and it is a common word, not specifically used in law. However, in The online Indonesian law dictionary, the word dianggap is not found. In English, "deemed" is a more formal word for 'considered'. Moreover, although this word can sometimes be used in a general text, this word belongs to legalese formal language as its history can be read in https:/ / www.merriam-webster.com/dictionary/deem. In contrast, in Indonesian, the word dianggap is not considered as a legal term or a legalese expression.

Furthermore, the fifth term found to be consistently translated is "compliance". This word as a single noun (not as part of a prepositional phrase, such as "in compliance with") means 'the action or fact of acting in accordance with a demand or a requirement' (TransLegal). This word is translated as kepatuhan in the four documents and, according to KBBI, it means 'obedience', which is not a specific word used only in legal documents but used for any topic or in general. The word kepatuhan is also not found in The online Indonesian law dictionary. The word "compliance" belongs to the formal language type in legal documents, while its translation in Indonesian is not considered a legal term.

The sixth term consistently translated is "hereby", which is used to emphasize something written in a document or to say that something is now official (TransLegal). It is considered an archaic word. In all documents, it is translated consistently as dengan ini, 'with this'. However, the expression dengan ini is not considered a legal expression in Indonesian and it is not found in The online Indonesian law dictionary. 


\subsection{INCONSISTENTLY TRANSLATED TERMS AND EXPRESSIONS}

Based on the data analysis, there are thirteen English legalese terms and expressions inconsistently translated into Indonesian (see Appendix 2). The first expressions discussed belong to the synonymy type as shown in Table 3.

\begin{tabular}{|l|l|c|}
\hline English (the source text) & \multicolumn{1}{|c|}{ Indonesian (the target text) } & Document \\
\hline \multirow{4}{*}{ terms and conditions } & syarat-syarat dan ketentuan-ketentuan & $\mathrm{A}$ \\
\cline { 2 - 3 } & syarat-syarat dan ketentuan & $\mathrm{B}$ \\
\cline { 2 - 3 } & ketentuan-ketentuan dan syarat-syarat & $\mathrm{C}$ \\
\cline { 2 - 3 } any and all & syarat dan ketentuan & $\mathrm{D}$ \\
\hline \multirow{5}{*}{} & segala dan semua & $\mathrm{A}$ \\
\cline { 2 - 3 } & setiap dan semua; setiap dan seluruh & $\mathrm{B}$ \\
\cline { 2 - 3 } & setiap dan seluruh & $\mathrm{C}$ \\
\cline { 2 - 3 } & setiap dan semua & $\mathrm{D}$ \\
\hline
\end{tabular}

Table 3. Synonymy expressions and their translations.

Based on TransLegal, "terms and conditions" refer to "the provisions that together form part of an agreement'. "Terms and conditions" are usually written by one party as a standard agreement and they are the requirements which must be fulfilled by all parties to the agreement. This expression belongs to the synonymy type since the word "terms" actually has the same meaning as the word "conditions". In fact, according to TransLegal, the word "condition" refers to 'an essential or material contract term'. Similarly, Bloomsbury's Dictionary of Law defines the word "condition" as "term of a contract or duty which has to be carried out as part of a contract, or something which has to be agreed before a contract becomes valid', while the word "terms" is defined as 'conditions or duties which have to be carried out as part of a contract, arrangements which have to be agreed before a contract is valid'. Moreover, Oxford Dictionary of Law shows the similar definition between "terms" and "conditions". In other words, those dictionaries of law indicate that the two words are essentially the same. Despite this, both words are often used together in legal documents, particularly those using legalese expressions. In some documents written in plain English, sometimes only the word "terms" is used. As pointed out in Table 3, the expression "terms and conditions" is not translated consistently in Indonesian legal documents. "Terms" can be translated as syarat-syarat and "conditions" is usually translated as ketentuanketentuan, although it also can be the other way around. In English, the expression is always "terms and conditions", and it is never "conditions and terms". However, in Indonesian language, there is no consistent translation for this term found in the four documents. The Indonesian translation of this synonymous term cannot be found in KBBI and The online Indonesian law dictionary. 
"Any and all" also belongs to the synonymy legalese type and it basically means 'all' (TransLegal). In Document B, there are two translation versions of this expression: setiap dan semua (which is the same as the translation in Document D) and setiap and seluruh (the same as the translation in Document C). Setiap is actually 'every' or 'each', semua means 'all' and seluruh means 'all' or 'entire'. In Document A, it is translated as segala dan semua, where segala means 'any'. In KBBI and The online Indonesian law dictionary, this expression cannot be found, which could be the reason there is no consistent expression of "any and all" in Indonesian.

Table 4 shows the English modal auxiliaries with their translations in documents A, B, C, and D.

\begin{tabular}{|l|l|c|}
\hline English (the source text) & \multicolumn{1}{|c|}{ Indonesian (the target text) } & Document \\
\hline \multirow{4}{*}{ shall } & harus; akan & $\mathrm{A}$ \\
\cline { 2 - 3 } & harus; akan; --- (not translated) & $\mathrm{B}$ \\
\cline { 2 - 3 } & akan; harus & $\mathrm{C}$ \\
\cline { 2 - 3 } & --- (not translated); akan & $\mathrm{D}$ \\
\hline \multirow{5}{*}{ may } & dapat; bisa & $\mathrm{A}$ \\
\cline { 2 - 3 } & dapat; --- (not translated) & $\mathrm{B}$ \\
\cline { 2 - 3 } & mungkin & $\mathrm{C}$ \\
\cline { 2 - 3 } & dapat; mungkin & $\mathrm{D}$ \\
\hline
\end{tabular}

Table 4. Modal auxiliaries in legal documents.

"Shall" is the most common used modal auxiliary in legal documents, and it is used to indicate that something must be done (obligation) according to TransLegal. It is also used to indicate that something will be done (future action). Occasionally, it has no meaning in some contexts. All these definitions of "shall" can be seen in Table 4. In documents A and C, "shall" is sometimes translated as harus, 'must' and sometimes akan, 'will', while in Document B it is translated as harus and akan, and sometimes it is not translated. In Document $\mathrm{D}$, sometimes it is not translated and sometimes it is translated as akan. Table 5 provides the examples. 


\begin{tabular}{|l|l|}
\hline Document A: & Document B: \\
ST1: ...the supplier shall supply... & ST3: Seller shall package all items... \\
TT1: ...pemasok harus memasok... & TT3: Penjual harus mengepak semua barang... \\
ST2: ...shall also apply... & ST4: Seller shall promptly... \\
TT2: ...akan berlaku... & TT4: Penjual akan dengan segera... \\
& ST5: ...shall constitute... \\
& TT5: ...merupakan ... \\
Document C: & Document D: \\
ST6: ...shall be applicable... & ST8: ...we shall be entitled... \\
TT6: ...akan berlaku.... & TT8: ...kami berhak... \\
\hline Document C: & Document D: \\
ST7: ... shall be subject to... & ST9: ... we shall pass on... \\
TT7: ...harus diperiksa... & TT9: ...kami akan melewatkan ... \\
\hline
\end{tabular}

Table 5. Examples of modal "shall" and its Indonesian translations. ${ }^{1}$

Moreover, the modal auxiliary "may" is used to express possibility (TransLegal) in legal documents, while in Indonesian translation it refers to mungkin, 'maybe' or 'possible' in documents $C$ and D and dapat, 'can' in documents A, B, and D, and in Document B it is sometimes not translated. Table 6 shows the examples:

\begin{tabular}{|l|l|}
\hline Document A: & Document B: \\
ST1: ...the buyer may assign... & ST3: Apple may, at its option, decline... \\
TT1: ... pembeli dapat menetapkan... & $\begin{array}{l}\text { TT3: Apple, atas pilihannya sendiri, dapat } \\
\text { menolak... }\end{array}$ \\
ST2: The Buyer may cancel a rejected & ST4: ....may be issued from time to time... \\
PO... & TT4: ...sebagaimana sewaktu-waktu \\
TT2: Pembeli bisa membatalkan ... PO yang & dikeluarkan.... \\
ditolak. & Document D: \\
\hline Document C: & ST6: .... we may increase our spread... \\
ST5: ...any liability which may be & TT6: ...kami dapat meningkatkan spread... \\
imposed... & \\
TT5: ...suatu kewajiban yang mungkin & \\
diberlakukan... & ST7: ...you may hold with Hirose... \\
& TT7: ...yang mungkin Anda miliki dengan \\
& Hirose... \\
\hline
\end{tabular}

Table 6. Examples of modal "may" and its Indonesian translations.

${ }^{1}$ In all tables, $\mathrm{ST}=$ Source text; TT = Target text; number refers to the number of data. 
Table 7 shows technical terms and expressions with their translations.

\begin{tabular}{|l|l|c|}
\hline English (the source text) & \multicolumn{1}{|c|}{ Indonesian (the target text) } & Document \\
\hline \multirow{4}{*}{ liability/liabilities } & tanggung jawab; liabilitas; kewajiban & $\mathrm{A}$ \\
\cline { 2 - 3 } & kewajiban & $\mathrm{B}$ \\
\cline { 2 - 3 } & kewajiban & $\mathrm{C}$ \\
\cline { 2 - 3 } & kewajiban; kerugian; tanggung jawab & $\mathrm{D}$ \\
\hline \multirow{5}{*}{ prevail } & digunakan & $\mathrm{A}$ \\
\cline { 2 - 3 } & berlaku & $\mathrm{B}$ \\
\cline { 2 - 3 } & berlaku & $\mathrm{C}$ \\
\cline { 2 - 3 } & mengatasi; berlaku & $\mathrm{D}$ \\
\hline
\end{tabular}

Table 7. Technical Terms.

Based on Table 7, the four agreements seem to agree that "liability" or "liabilities" should be translated as kewajiban, 'obligation'. However, in Documents A and D, this term is also translated by several different words, such as tanggung jawab, 'responsibility', liabilitas, 'liability', and kerugian, 'loss'. The term "liability" according to TransLegal refers to 'legal responsibility for acts or omissions (failures to act, especially when we should have)'. In KBBI, the words kewajiban, tanggung jawab, liabilitas, and kerugian have their own meaning as can be seen in Table 8. In this dictionary, only the words kewajiban and tanggung jawab are labelled as Huk.

\begin{tabular}{|l|l|}
\hline kewajiban & something that must be done, an obligation, a duty \\
\hline tanggung jawab & a mandatory state to deal with things \\
\hline liabilitas & a person who hinders something from happening \\
\hline kerugian & suffering from losses \\
\hline
\end{tabular}

Table 8. Definitions based on KBBI.

Meanwhile, according to The online Indonesian law dictionary, the definition of each word can be seen in Table 9 .

\begin{tabular}{|l|l|}
\hline kewajiban & the burden imposed by law on an individual or a legal entity \\
\hline tanggung jawab & not found \\
\hline liabilitas & not found \\
\hline kerugian & in relation to the loss of state wealth \\
\hline
\end{tabular}

Table 9. Definitions based on The online Indonesian law dictionary.

The definitions indicate that the closest translation of "liability" in Indonesian is kewajiban which is also considered a legal term. 
The term "prevail" means 'to win through' according to TransLegal. Furthermore, it explains that when an idea, opinion, or argument prevails, especially after a struggle or much effort, it has been accepted or it applies. In the four documents, it is translated by several words in Indonesian. In Document A, it is translated as digunakan from a clause "the parties agree that the English version shall prevail" (maka semua pihak setuju bahwa versi Inggris yang akan digunakan). In Documents B, C, and D, it is translated as berlaku in the clauses, such as "the terms and conditions of this Agreement shall prevail" (syarat-syarat dan ketentuan Perjanjian ini berlaku) and "the English text shall prevail" (maka teks bahasa Inggris yang berlaku). In Document D, it is translated as mengatasi in the sentence "the DSA Rules will prevail over this Agreement if there is any conflict with them" (Peraturan FSA akan mengatasi Perjanjian ini jika terdapat konflik). The translation of Document A is actually not wrong but, if the word digunakan is replaced with berlaku, the meaning will be the same and it will sound more "Indonesian legalese". Documents B and C already have a proper translation of the term, while in Document $\mathrm{D}$ the translation of "prevail" does not seem to be successful. It should be translated as berlaku to express the same message from the source text. The terms "prevail" and "apply" do refer to a similar meaning in legal documents.

Table 10 shows terms and expressions of formal language and their translations. The first one is "expressly" which has the same meaning as 'clearly and intentionally stated' based on TransLegal, and it is a formal form. In Document $\mathrm{A}$, it is sometimes not translated, such as in the phrase "unless expressly agreed" (kecuali jika disetujui); the word jika, 'if' is not the translation of "expressly", but belongs to the meaning of the word "unless". However, sometimes it is translated as secara tersurat, 'literally' (see Appendix 2). In Document B, it is translated as dengan tegas, 'assertively' and in Document $C$ it is translated as secara tegas, 'assertively', where both expressions have the same meaning in Indonesian language. Moreover, in Document $C$ it is translated as dengan ini, 'hereby'. However, those expressions cannot be found in The online Indonesian law dictionary and they can be used in any types of texts. In Document D, the term "expressly" is not found.

The second term is "termination", which refers to 'the act of ending something so that it no longer exists and refers to a contract, an agreement, et cetera' (TransLegal). This word is more formal than "ending". This word is translated into several words in Indonesian. In Document A, it is translated as pemutusan and pengakhiran. In Documents B and C, it is translated as pengakhiran. In Document $\mathrm{D}$, it is translated as penghentian. The words pengakhiran and penghentian have the same meaning according to KBBI, namely: 'stopping' or 'ending something'. However, the word pemutusan refers to 'deciding' or 'determining' (KBBI). In The online Indonesian law dictionary, those three words are not found or not considered as legal terms.

The third word is "otherwise", which means 'differently, in another way, or in circumstances different from those being considered' (TransLegal). It is a formal form of "or" and often used in legal documents. In Document A, 
it is translated as lainnya, 'another', or 'others', sebaliknya, 'on the contrary' and dengan cara lain, 'in another way', but sometimes it is not translated. In Document B, it is translated as lainnya and lain, 'another', or 'others'. In Document C, it is translated as yang lain, 'another' or 'others' and sebaliknya, and in Document D, it is translated as lain and sebaliknya. It seems that the proper translation of "otherwise" in legal documents in Indonesian is best as dengan cara lain, lainnya, and lain. The word sebaliknya does not really express the meaning of "otherwise" since it expresses contrast. All those Indonesian words, however, are not considered legal terms or expressions and they cannot be found in The online Indonesian law dictionary.

\begin{tabular}{|l|l|c|}
\hline English (the source text) & \multicolumn{1}{|c|}{ Indonesian (the target text) } & Document \\
\hline \multirow{5}{*}{ expressly } & --- (not translated); secara tersurat & $\mathrm{A}$ \\
\cline { 2 - 3 } & dengan tegas & $\mathrm{B}$ \\
\cline { 2 - 3 } & secara tegas; dengan ini & $\mathrm{C}$ \\
\cline { 2 - 3 } & not found & $\mathrm{D}$ \\
\hline \multirow{5}{*}{ termination } & pemutusan; pengakhiran & $\mathrm{A}$ \\
\cline { 2 - 3 } & pengakhiran & $\mathrm{B}$ \\
\cline { 2 - 3 } & pengakhiran & $\mathrm{C}$ \\
\cline { 2 - 3 } & penghentian & $\mathrm{D}$ \\
\hline \multirow{5}{*}{ otherwise } & $\begin{array}{l}\text { lainnya; sebaliknya; --- (not translated); } \\
\text { dengan cara lain }\end{array}$ & $\mathrm{A}$ \\
\cline { 2 - 3 } & lainnya; lain & $\mathrm{B}$ \\
\cline { 2 - 3 } & yang lain; sebaliknya & $\mathrm{C}$ \\
\cline { 2 - 3 } & lain; sebaliknya & \\
\hline
\end{tabular}

Table 10. Formal language.

Table 11 shows the archaic words with their translations. The first word is "notwithstanding" which refers to 'in spite of' or 'despite the fact or thing mentioned' (TransLegal). It is translated as tampa mengabaikan and dengan tidak mengindahkan which both mean 'without ignoring' in Document B; meskipun, 'although', 'even though', 'in spite of', or 'despite' in Document C; and tidak termasuk, 'not including' in Document D. This word is not found in Document A. Based on the definition in TransLegal, it seems that the only suitable translation is meskipun, but this word is a common word (a connector), not considered as a specifically legal term. According to some professional legal translators, "notwithstanding" should be translated as dengan tidak mengindahkan, yet this expression is not found in The online Indonesian law dictionary.

The second expression of the archaic language found is "pursuant to". It has the same meaning as 'in accordance with, relating to, or concerning a law, resolution, contract, or other legal documents' (TransLegal). In Document A, it 
is translated as sesuai dengan, 'in accordance with', 'relating to', or 'concerning' and atas, 'on'. In Documents B and D, it is translated as berdasarkan, 'based on' and in Document $C$ it is translated as menurut, 'according to'. Based on the meaning, it appears that the most suitable translation is sesuai dengan. However, all these Indonesian words are not considered Indonesian legal terms or legalese as none of them is found in The online Indonesian law dictionary. In other words, those words or expressions are just common ones used in any text types.

\begin{tabular}{|c|l|c|}
\hline English (the source text) & \multicolumn{1}{|c|}{ Indonesian (the target text) } & Document \\
\hline \multirow{4}{*}{ notwithstanding } & not found & $\mathrm{A}$ \\
\cline { 2 - 3 } & tanpa mengabaikan; dengan tidakmengindahkan & $\mathrm{B}$ \\
\cline { 2 - 3 } & meskipun & $\mathrm{C}$ \\
\cline { 2 - 3 } & tidak termasuk & $\mathrm{D}$ \\
\hline \multirow{5}{*}{ pursuant to } & sesuai dengan; atas & $\mathrm{A}$ \\
\cline { 2 - 3 } & berdasarkan & $\mathrm{B}$ \\
\cline { 2 - 3 } & menurut & $\mathrm{C}$ \\
\cline { 2 - 3 } & berdasarkan & $\mathrm{D}$ \\
\hline
\end{tabular}

Table 11. Archaic words.

Table 12 shows the fixed expressions with their translations. The first one is "in the event" which has the same meaning as 'if' (TransLegal). It is translated as jika, 'if' in Document A, apabila, 'if' or 'when' in Document B and dalam hal, 'in the matter of' in Documents A, C, and D. This fixed expression appears more in English legal documents than the connector "if", and in Indonesian legal documents the expression dalam hal appears more frequently than the words jika and apabila, even though this expression is not found in The online Indonesian law dictionary. Similarly, the words jika and apabila are not found in the law dictionary, as they are common words, not specifically used in legal documents. The second expression is "including but not limited to" or "including and without limitation", which actually means 'including' based on an online blog discussing the legal terms and expressions (http:/ / www. lawprose.org/lawprose-lesson-226-including-but-not-limited-to/). The blog (Garner 2015) explains that this expression is part of the verbosity (too wordy expression) which is one of the characteristics of legalese. In Documents A and $\mathrm{B}$, it is translated as termasuk namun tidak terbatas pada, in Document C as termasuk tetapi tidak terbatas pada and in Document D as meliputi dan tidak terbatas. All three of them have the same meaning, but the first two expressions seem to appear more frequently than that in Document D. However, all these Indonesian expressions are not listed yet in The online Indonesian law dictionary. 


\begin{tabular}{|l|l|c|}
\hline English (the source text) & \multicolumn{1}{|c|}{ Indonesian (the target text) } & Document \\
\hline \multirow{4}{*}{ In the event } & dalam hal; jika & $\mathrm{A}$ \\
\cline { 2 - 3 } & apabila & $\mathrm{B}$ \\
\cline { 2 - 3 } & dalam hal & $\mathrm{C}$ \\
\cline { 2 - 3 } & dalam hal & $\mathrm{D}$ \\
\hline \multirow{3}{*}{$\begin{array}{l}\text { Including but not limited } \\
\text { to/including and without } \\
\text { limitation }\end{array}$} & termasuk namun tidak terbatas pada & $\mathrm{A}$ \\
\cline { 2 - 3 } & termasuk namun tidak terbatas pada & $\mathrm{B}$ \\
\cline { 2 - 3 } & termasuk tetapi tidak terbatas pada & $\mathrm{C}$ \\
\cline { 2 - 3 } & meliputi dan tidak terbatas & $\mathrm{D}$ \\
\hline
\end{tabular}

Table 12. Fixed Expression.

\section{CONCLUSION}

To conclude, based on the analysis, we have discovered only six out of seven types of legal language in Indonesian documents. One type, foreign words, is not found in all the documents researched. Of the six types, six terms are consistently translated which cannot be said of the other thirteen terms and expressions. Only a few words of the Indonesian translations, such as berlaku, mengikat, and kewajiban, are considered legal terms as they are listed in The online Indonesian law dictionary consulted in the writing of this paper, although not all of them are marked with the Huk label in KBBI. This also shows that there is still inconsistency about what words are considered as legalese in Indonesian between different dictionaries.

The translations of the rest of the sixteen terms and expressions are all just considered common words and expressions which can be looked up in KBBI but not in the Indonesian law dictionary. This discovery leads to several assumptions that: (1) Indonesian legalese terms and expressions are not yet established, unlike English legalese; (2) the Indonesian law dictionary has not included the terms and expressions usually used in Indonesian legal documents; (3) inconsistency and perhaps errors in the translation from English legalese terms and expressions to Indonesian will continue to appear quite frequently if the issues arising from (1) and (2) have not been dealt with and resolved. The result of this paper is limited to the data found in those four open-accessed documents, so further research into different types of legal documents, such as regulations, laws, MOUs and others, is required to obtain more conclusive evidence on the almost non-existent Indonesian legal terms and expressions.

\section{REFERENCES}

Bernadrova-Gibová, Klaudia. 2011. “On modality in EU Institutional-Legal Texts", in: Alena Kačmárová (ed.), English matters II, pp. 6-12. Prešov: Prešovská univerzita.

Black, Henry C. 1910. "Legalese", in: Black's law dictionary. Second edition.

[Retrieved from: https://thelawdictionary.org/legalese] 
Cao, Deborah. 2007. Translating law. Clevedon: Multilingual Matters.

Collins, Peter H. 2004. Dictionary of law. Fourth edition. London: Bloomsbury Publishing.

Corsino, Bruce. 2020. “What's the only word that means mandatory? Here's what law and policy say about 'shall, will, may, and must'", in: Federal aviation administration. [Retrieved from: https://www.faa.gov/about/ initiatives/plain_language/articles/mandatory/]

Chen, Yan and Dai Yun. 2014. "On the language features of English contract translation", International Journal of Language and Linguistics. Special Issue: "The Sociolinguistics of a changing world", Vol. 2(6-2): 1-5. [DOI: 10.11648/j.ijll.s.2014020602.11]

Dwidjodarmo, Paulus M. 1973. Istilah-istilah hukum bahasa Belanda. Jakarta: Karya Nusantara.

Fiorito, Lorenzo. 2006. "On performatives in legal discourse", Metalogicon, XIX/2: 101-112. [Retrieved from: http://www.metalogicon.org/ rivista/2006ld/Fiorito06ld.pdf]

Garner, Bryan A. 2015. “September 2. LawProse Lesson \#226: 'including but not limited to'" [Blog post]. [Retrieved from http:// www.lawprose.org/ lawprose-lesson-226-including-but-not-limited-to/; accessed in June 2018.]

Garner, Bryan A. and Henry C. Black. 2004. Black's law dictionary. St. Paul, MN: Thomson/West.

Goźdź-Roszkowski, S. 2013. “Exploring near-synonymous terms in legal language; A corpus-based, phraseological perspective”, Linguistica Antverpiensia 12: 94-109.

Harkrisnowo, Harkristuti. 2007. Bahasa Indonesia sebagai sarana pengembangan hukum nasional. [Retrieved from: http:/ / www.legalitas.org/?q=node/67]

Hastuti, Endang D. 2007. "Analisis terjemahan istilah-istilah hukum dalam buku teks Intelectual Property Rights; Kajian strategi penerjemahan, ketepatan dan kealamiahan terjemahan". [Unpublished Master's thesis, Universitas Sebelas Maret, Surakarta.]

Kamus Besar Bahasa Indonesia Online. n.d. [Retrieved from: https://kbbi. kemdikbud.go.id/]

Kamus Hukum Online Indonesia. n.d. [Retrieved from: https:/ / kamushukum. web.id]

Krapivkina, Olga. 2017. "Semantics of the verb shall in legal discourse", Jezikoslovlje 18: 305-317.

Khairani, Ade I. 2008. “Analisis strategi penerjemahan Inggris-Indonesia dalam teks Kontrak Umum Perjanjian Kerja”. Master's thesis, Universitas Sumatera Utara, Medan. [Retrieved from: http://repository.usu.ac.id/ handle/123456789/5773]

Law, Jonathan and Elizabeth A. Martin. 2009. Oxford dictionary of law. Oxford University Press.

Law of the Republic of Indonesia No. 24/2009 on the National Flag, Language, Emblem and Anthem.

Massier, Ab and Marjanne Termorshuizen-Arts. 2000. Indonesisch-Nederlands woordenboek privaatrecht; Verbintenissenrecht. Leiden: KITLV Uitgeverij. 
Merriam-Webster. n.d. [Accessed from: https://www.merriam-webster. com/dictionary]

Pascarina, Hanifa, Mangatur Nababan, and Riyadi Santosa. 2017. "Loss dan Gain pada terjemahan buku hukum The concept of law karya H.L.A. Hart ke dalam versi bahasa Indonesia 'Konsep Hukum'", Prasasti: Journal of Linguistics 2(2): 237-252. [Retrieved from: https://jurnal.uns.ac.id/pjl/ article/download/1374/12744]

Qamar, Nurul and Hardianto Djanggih. 2017. "Peranan bahasa hukum dalam perumusan norma Perundang-undangan", JIKH Vol. 11(3): 337-347. [Retrieved from: http://ejournal. balitbangham.go.id/index.php/ kebijakan/article/view/288/pdf]

Termorshuizen-Arts, Marjanne. 1999. Nederlands-Indonesisch juridisch woordenboek. Leiden: Brill.

TransLegal. The World Law Dictionary Project. n.d. [Accessed from: https:/ / www.translegal.com/legal-english-dictionary]

Verentina-Chiriac, Ina. 2012. "Characteristics and features of legal English vocabulary", Revistă Ştiințifică a Universității de Stat din Moldova 4(54): 103-107. [Retrieved from: http://studiamsu.eu/wp-content/uploads/20.-p.103-107. pdf]

Wijayanti, Sri H. 2009. Bahasa Hukum Indonesia di dalam Surat Perjanjian. [Retrieved from http:/ / www.atmajaya.ac.id/web/KontenUnit.aspx?gid=artikelhkiandou=hkiandcid=artikel-hki-bahasa-hukum-indonesia]

Wuryantoro, Aris, D. Edi Subroto, and Mangatur Nababan. 2014. "Translation techniques on Indonesian Sworn Translator's legal texts translation", English Teaching Journal, Vol. 2/2 (December): 41-49. [Retrieved from: http:/ / download.portalgaruda.org]

\section{About The Authors}

HARU DELIANA DEWI is the coordinator of the Master's Degree Programme of the Applied Linguistics, Translation of the Faculty of Humanities, Universitas Indonesia and a full member of HPI (Indonesian Translators' Association) since 2016. Her research interests are translation pedagogy, translation theory and practice, and academic translation. Her most recent publications are Dasar-dasar penerjemahan umum (Introduction to general translation, with Andika Wijaya, edited by Rahayu S. Hidayat, Bandung: Penerbit Manggu, 2020) and "The effectiveness between two translation assessment models for English to Indonesian translation of undergraduate students", Journal of Language and Literature 20/2 (October, 2020: 270-287). Haru Deliana Dewi can be contacted at: harudd.dewi7@gmail.com.

ANDIKA WIJAYA is a faculty member at the English Studies Programme, Universitas Indonesia and a full member of HPI (Indonesian Translators' Association). In 2015 he received his Master of Translating and Interpreting from RMIT University and got a certification as a professional English-Indonesian translator from the National Accreditation Authority for Translators and Interpreters (NAATI), Australia. He is the Manager of Translating and Interpreting Program at LBI UI. His recent publications include "Translation of nonstandard language and readability; Analysis of Joseph's speech in an Indonesian version of Wuthering Heights ", SKASE Journal of Translation and Interpretation 13/1 (2020: 34-49) and a co-authored of Dasar-dasar penerjemahan umum (with Haru Deliana Dewi, edited by Rahayu S. Hidayat, Bandung: Penerbit Manggu, 2020,). His research interests include cross-cultural translations, translation and popular culture, and censorship in translations. Andika Wijaya can be contacted at: andika.wijaya@ui.ac.id. 
RAHAYU SURTIATI HIDAYAT has been retired recently from her position as senior lecturer of translation studies and educational linguistics in the Master's Degree Programme of the Applied Linguistics, Translation of the Faculty of Humanities, Universitas Indonesia. She is a translator mostly from French to Indonesian, a member of Himpunan Penerjemah Indonesia (Indonesian Translators' Association) since 1990 and a member of its Advisory Council since 2010. She has been Editor in Chief of Paradigma, Jurnal Kajian Budaya since 2016. Rahayu Surtiati Hidayat can be contacted at: rahayu.surtiati@gmail.com. 


\begin{tabular}{|c|c|c|c|c|c|c|c|}
\hline & & & 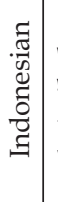 & 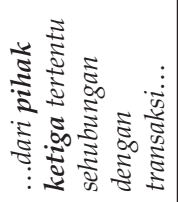 & 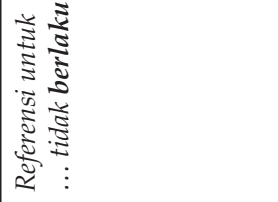 & 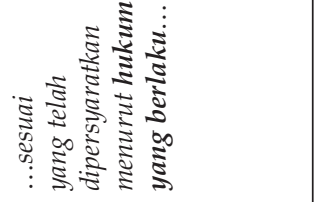 & 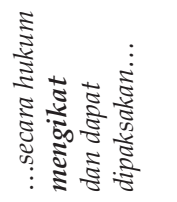 \\
\hline & & $\infty$ & 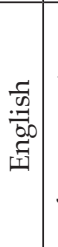 & 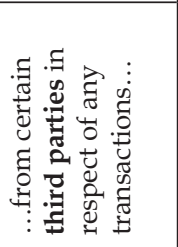 & 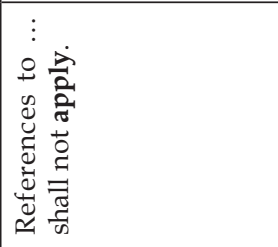 & 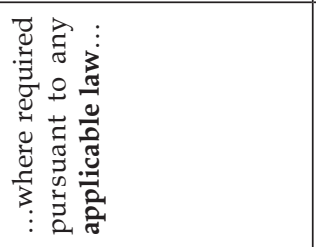 & 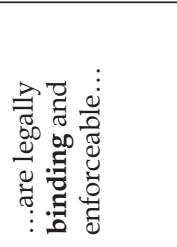 \\
\hline & & & 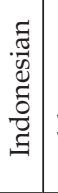 & 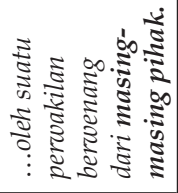 & 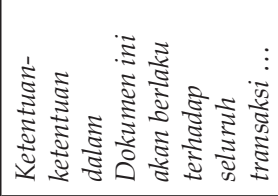 & 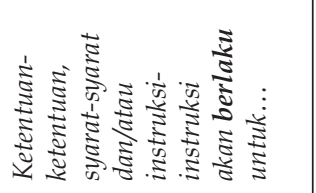 & 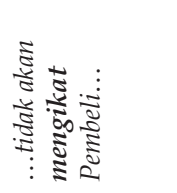 \\
\hline & 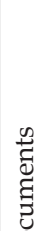 & 0 & 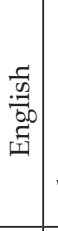 & 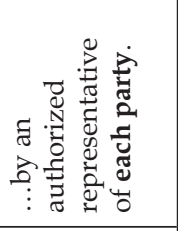 & 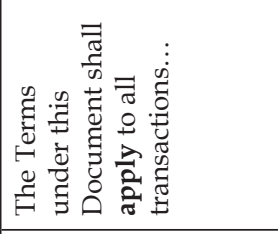 & 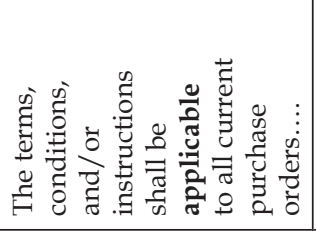 & 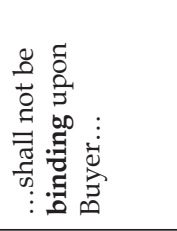 \\
\hline & ๑̊ & $\infty$ & 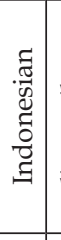 & 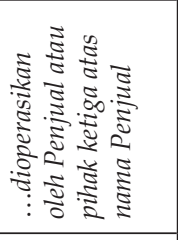 & 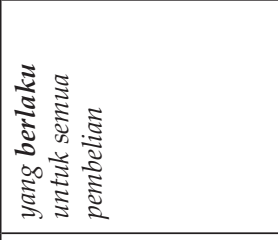 & 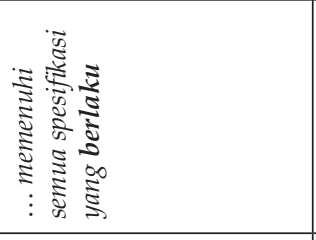 & 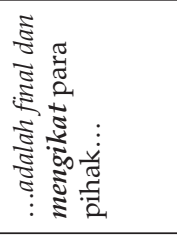 \\
\hline & & & 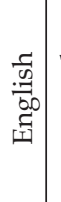 & 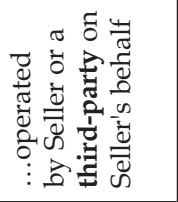 & 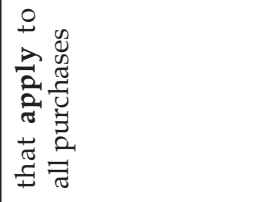 & 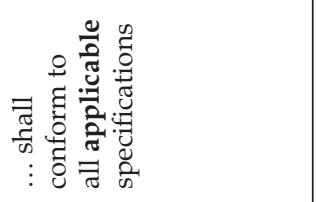 & 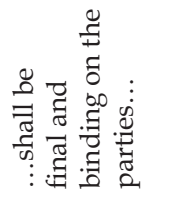 \\
\hline & & 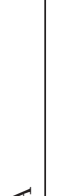 & 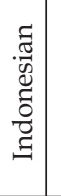 & 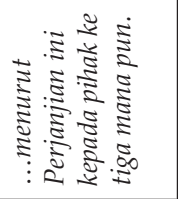 & 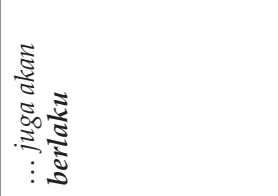 & 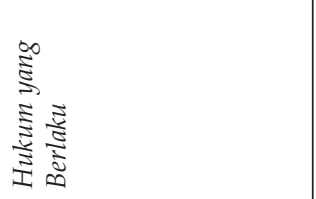 & 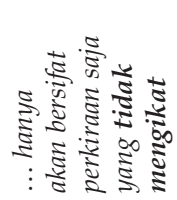 \\
\hline 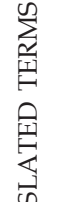 & & & 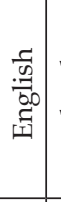 & 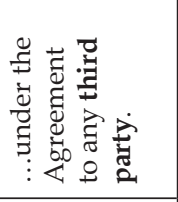 & $\begin{array}{l}0 \\
\frac{0}{0} \\
\frac{\pi}{\sigma} \\
\frac{\pi}{5} \\
\frac{2}{n} \\
\vdots \\
\vdots \\
\frac{\pi}{2}\end{array}$ & 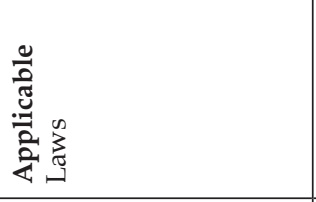 & 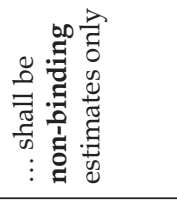 \\
\hline 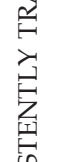 & 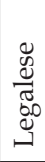 & & & 总 & $\frac{\overrightarrow{2}}{2}$ & $\begin{array}{l}\frac{0}{0} \\
\frac{\pi}{2} \\
\frac{0}{2} \\
\frac{2}{4}\end{array}$ & 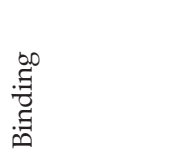 \\
\hline$\dot{0}$ & Z̊ & & & $r$ & $N$ & & $\infty$ \\
\hline
\end{tabular}




\begin{tabular}{|c|c|c|}
\hline 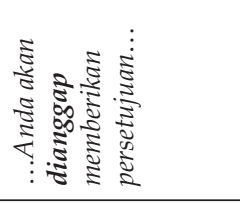 & 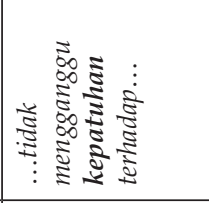 & 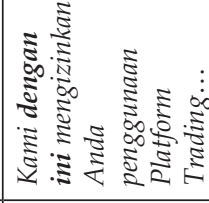 \\
\hline 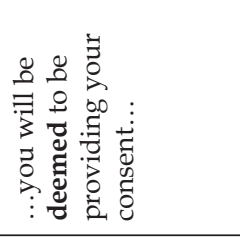 & 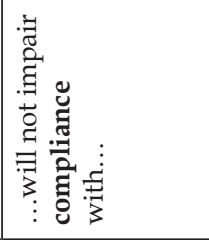 & 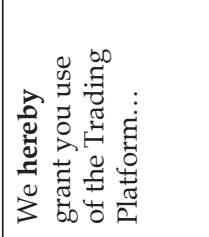 \\
\hline 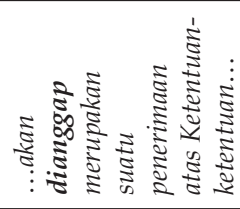 & 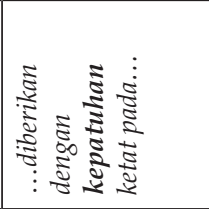 & 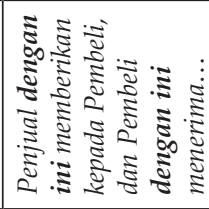 \\
\hline 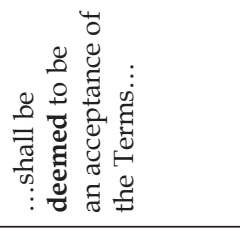 & 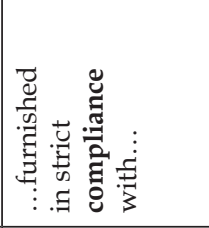 & 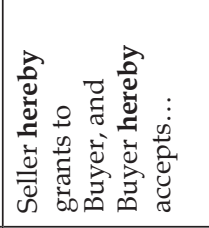 \\
\hline 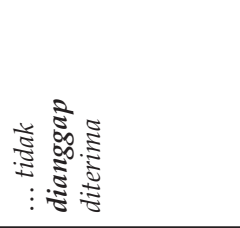 & 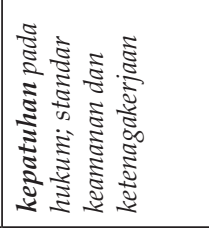 & 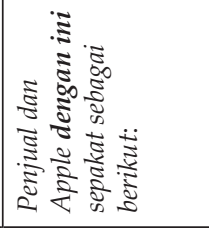 \\
\hline 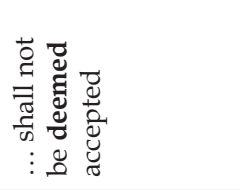 & 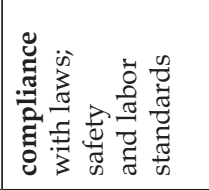 & 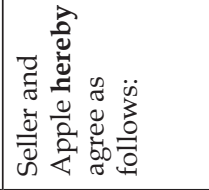 \\
\hline 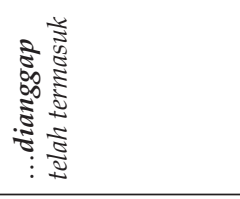 & 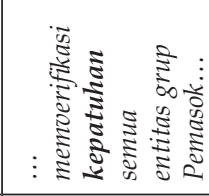 & 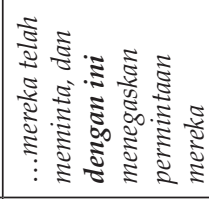 \\
\hline 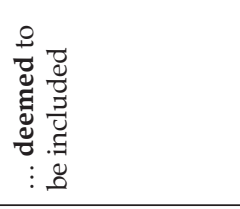 & 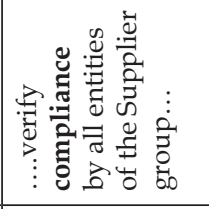 & 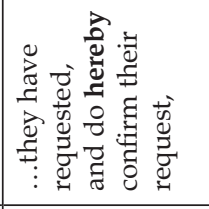 \\
\hline \begin{tabular}{|l} 
\\
$\tilde{\Xi}$ \\
$\tilde{\Xi}$ \\
$\tilde{\Xi}$ \\
\end{tabular} & 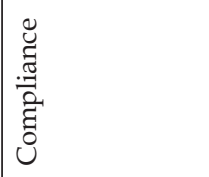 & 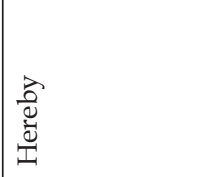 \\
\hline$H$ & 10 & 6 \\
\hline
\end{tabular}




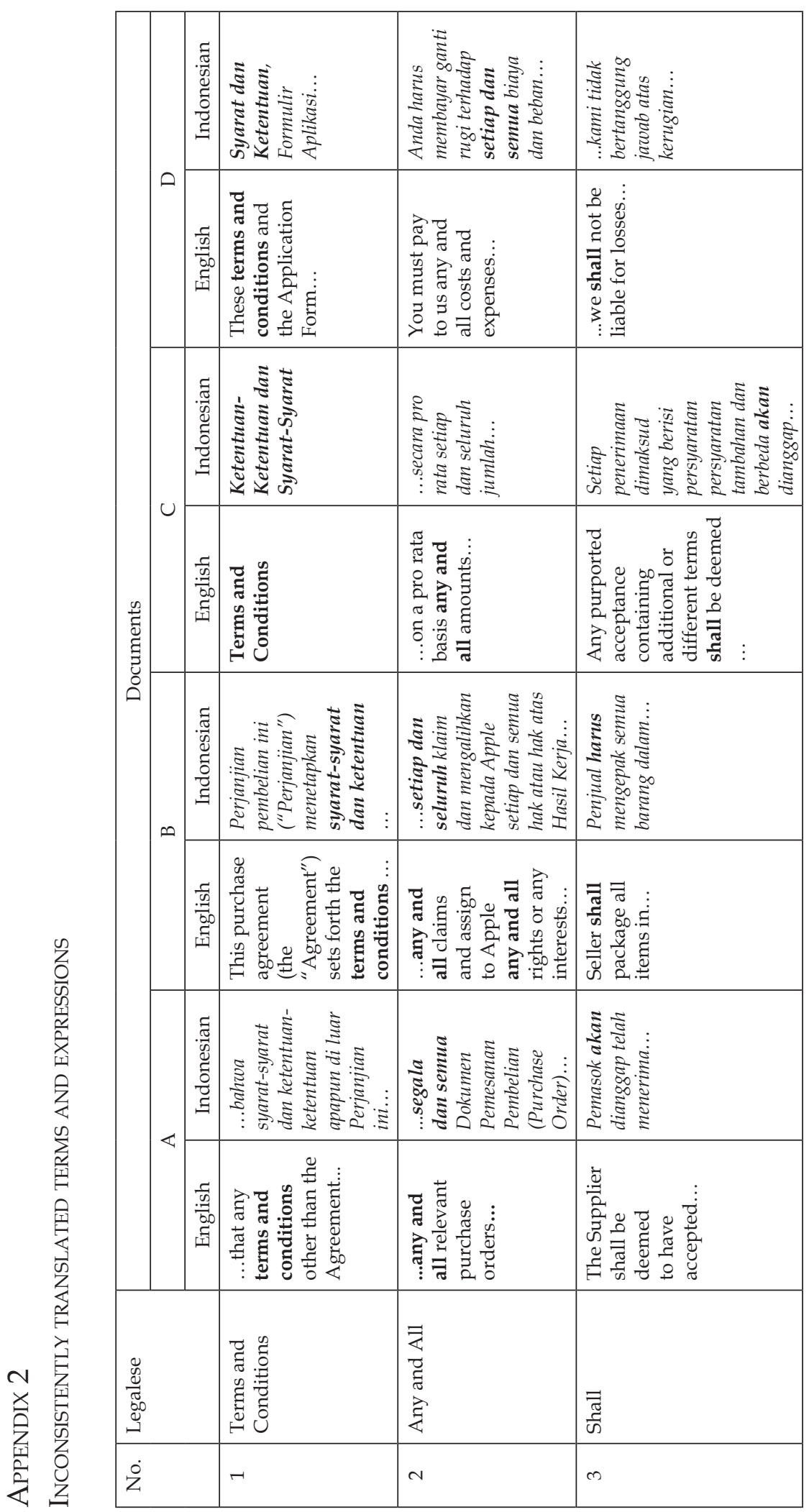




\begin{tabular}{|c|c|c|c|}
\hline 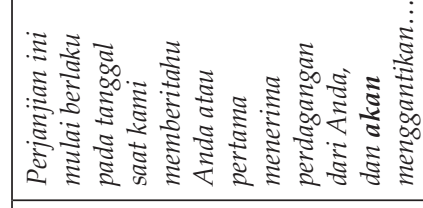 & & 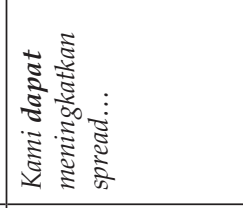 & 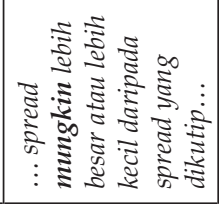 \\
\hline 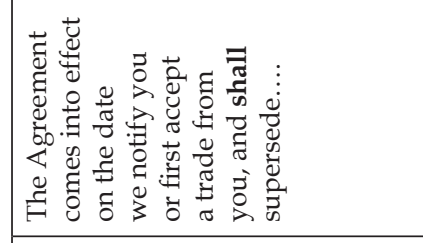 & & 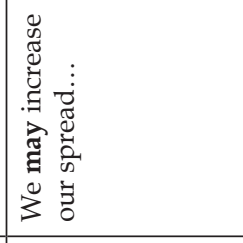 & 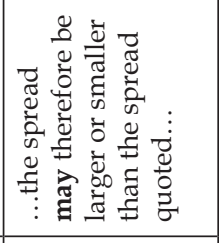 \\
\hline 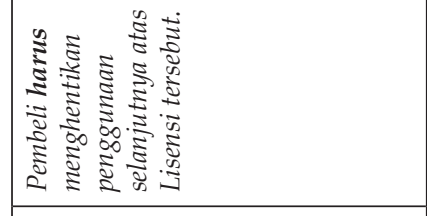 & & 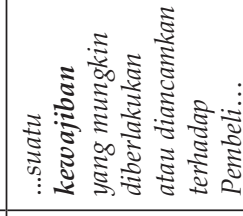 & \\
\hline 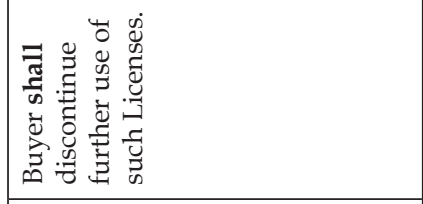 & & 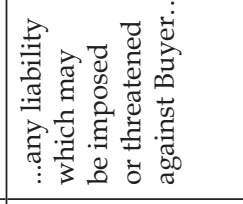 & \\
\hline 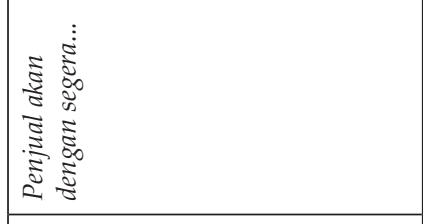 & 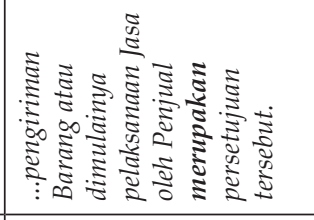 & 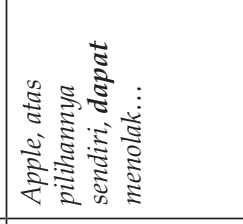 & \\
\hline 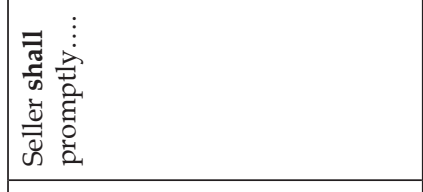 & 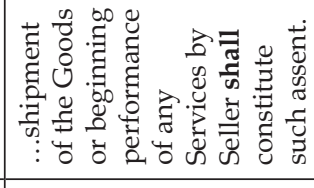 & 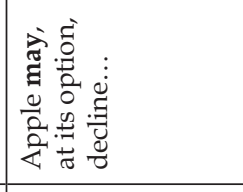 & \\
\hline 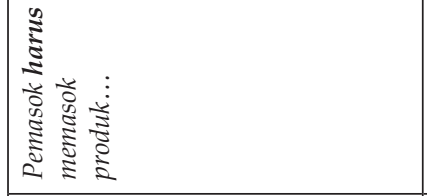 & & 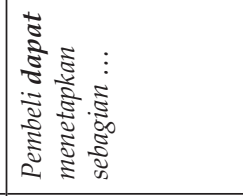 & 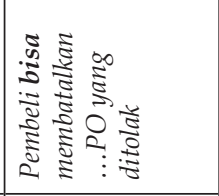 \\
\hline 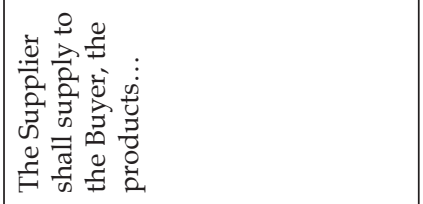 & & 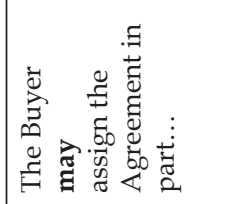 & 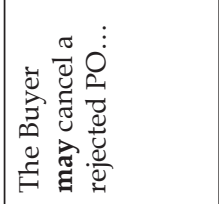 \\
\hline & & $\stackrel{\vec{\pi}}{\Sigma}$ & \\
\hline & & $H$ & \\
\hline
\end{tabular}




\begin{tabular}{|c|c|c|c|c|}
\hline 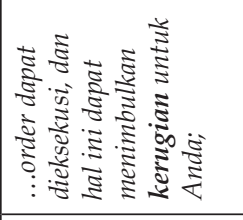 & 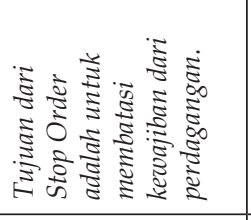 & 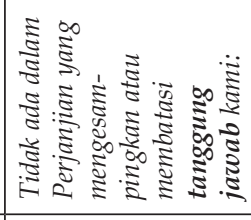 & 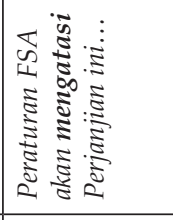 & 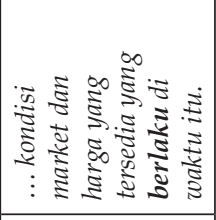 \\
\hline 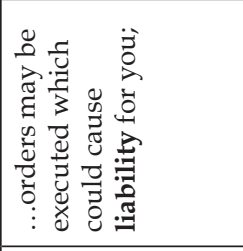 & 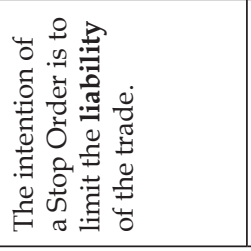 & 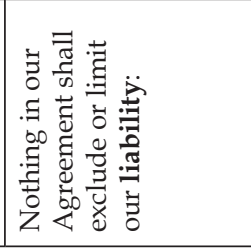 & 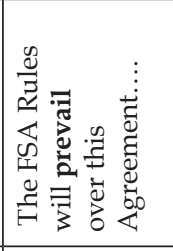 & 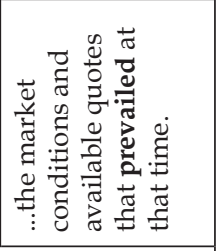 \\
\hline \multicolumn{3}{|l|}{ 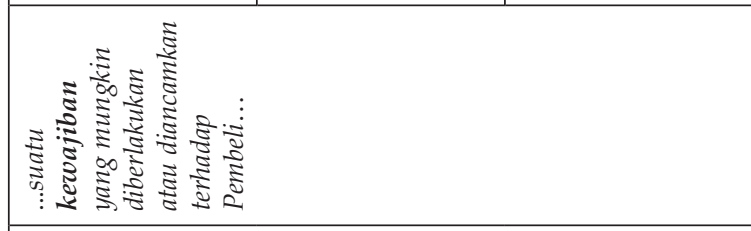 } & \multicolumn{2}{|l|}{ 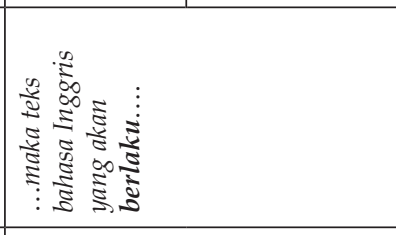 } \\
\hline \multicolumn{3}{|l|}{ 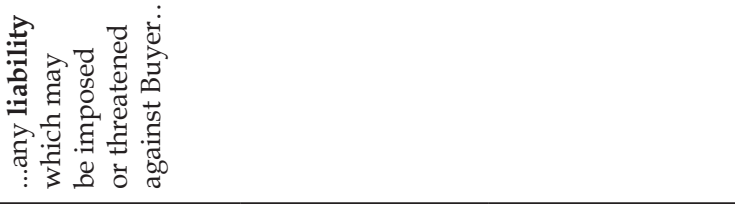 } & \multicolumn{2}{|l|}{ 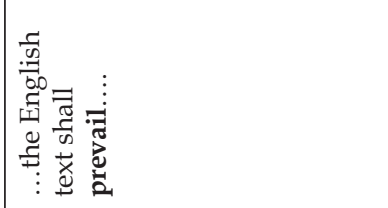 } \\
\hline \multicolumn{3}{|c|}{ 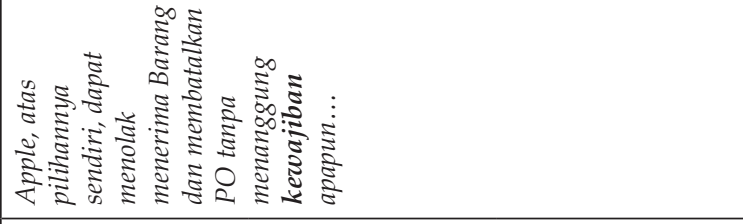 } & \multicolumn{2}{|l|}{ 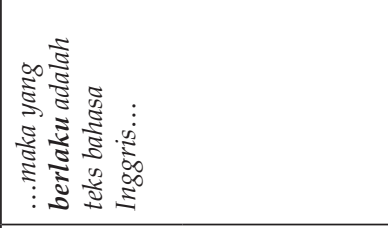 } \\
\hline \multicolumn{3}{|c|}{ 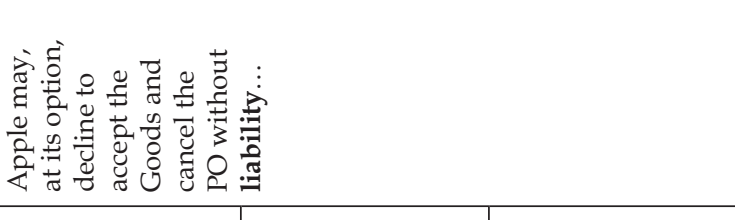 } & \multicolumn{2}{|l|}{ 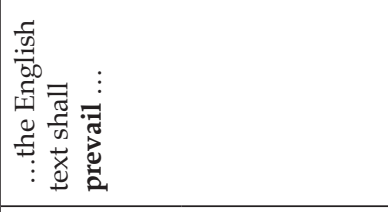 } \\
\hline 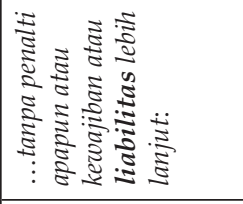 & 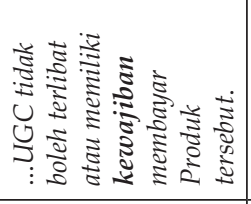 & 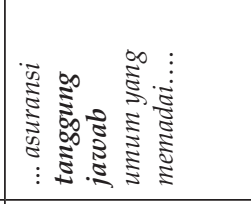 & \multicolumn{2}{|c|}{ 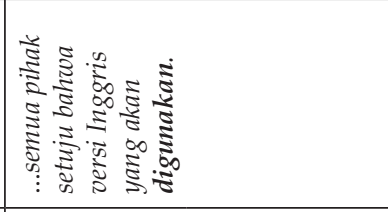 } \\
\hline 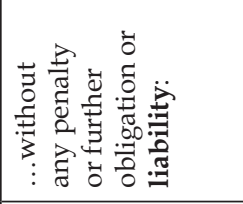 & 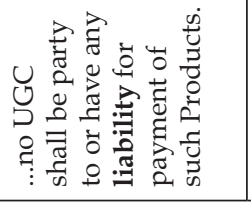 & 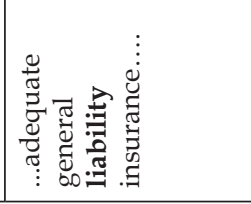 & \multicolumn{2}{|c|}{ 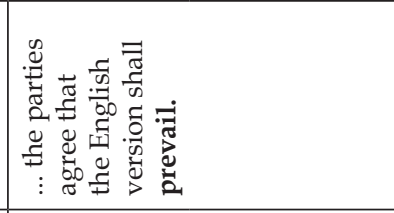 } \\
\hline \multicolumn{3}{|l|}{ 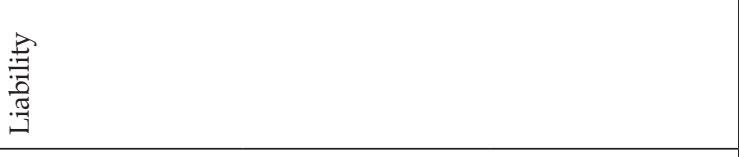 } & \multicolumn{2}{|l|}{ 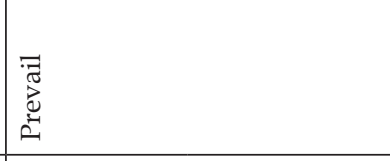 } \\
\hline \multicolumn{3}{|l|}{ n) } & \multicolumn{2}{|l|}{0} \\
\hline
\end{tabular}




\begin{tabular}{|c|c|c|c|}
\hline 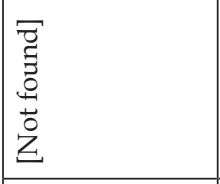 & & 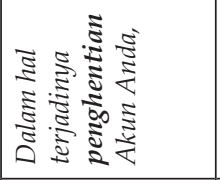 & \\
\hline 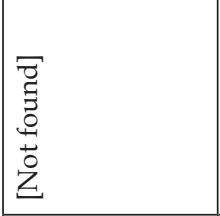 & & 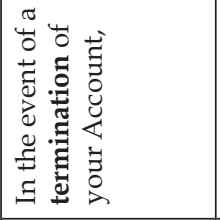 & \\
\hline 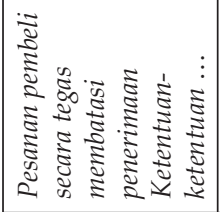 & 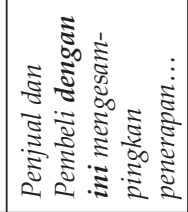 & 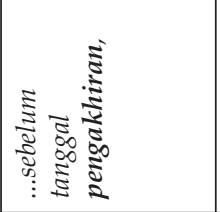 & \\
\hline 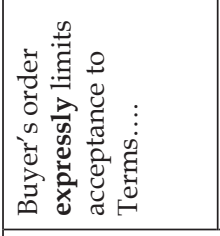 & 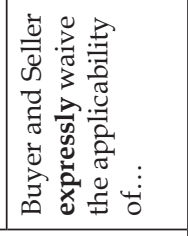 & 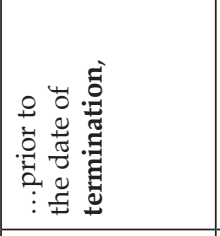 & \\
\hline 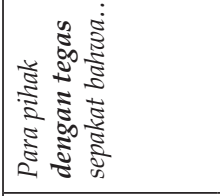 & & 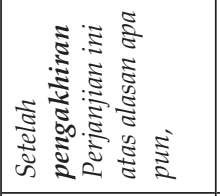 & \\
\hline 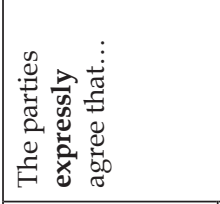 & & 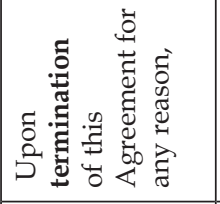 & \\
\hline 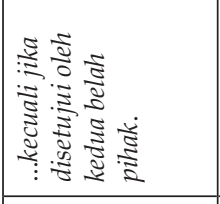 & 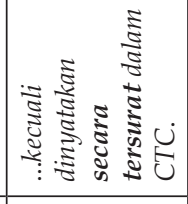 & 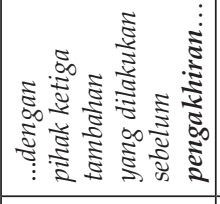 & 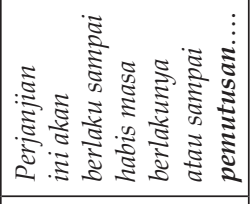 \\
\hline 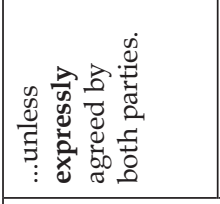 & 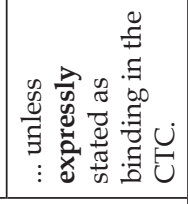 & 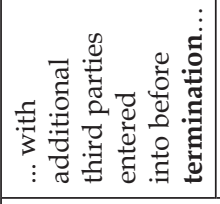 & 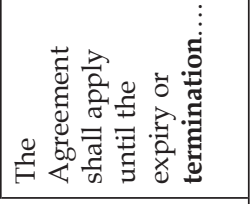 \\
\hline 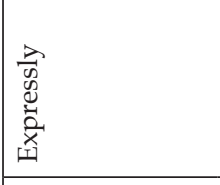 & & 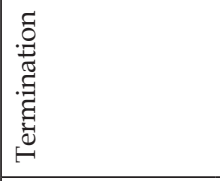 & \\
\hline$\Lambda$ & & $\infty$ & \\
\hline
\end{tabular}




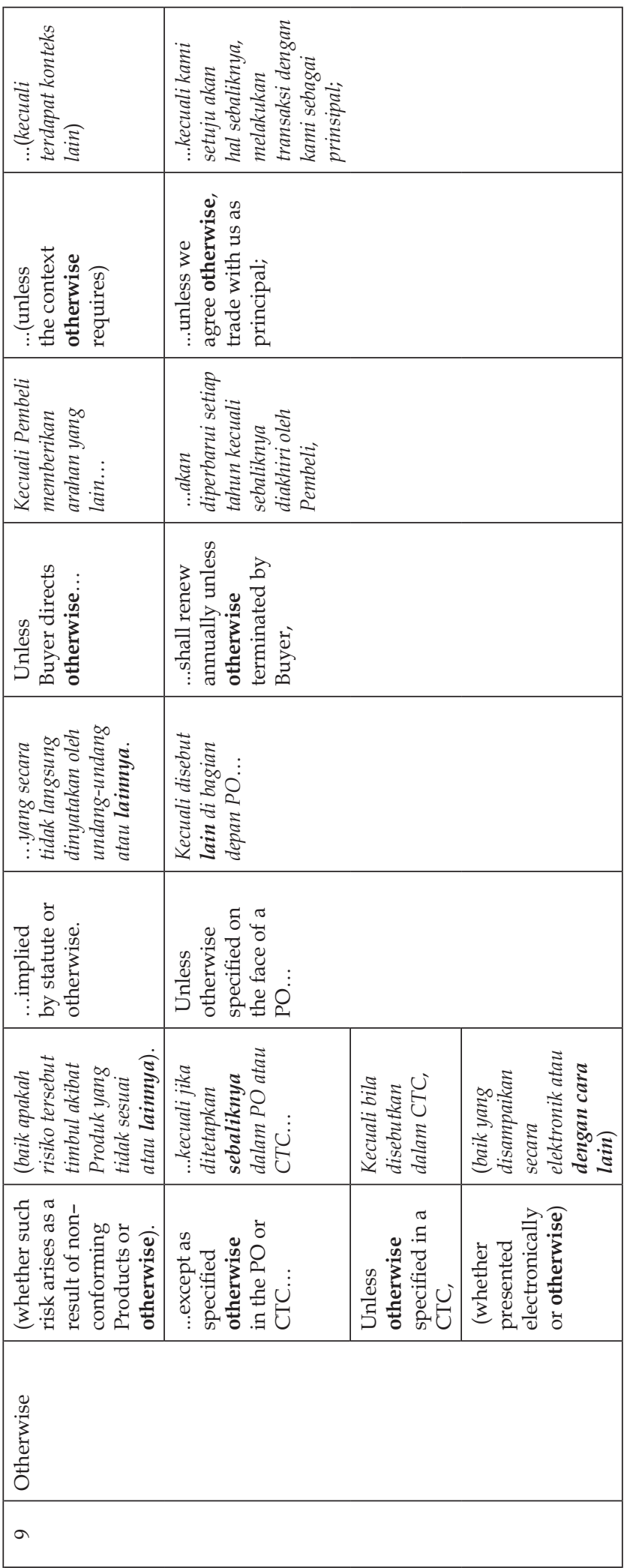




\begin{tabular}{|c|c|c|c|c|}
\hline \multicolumn{2}{|l|}{ 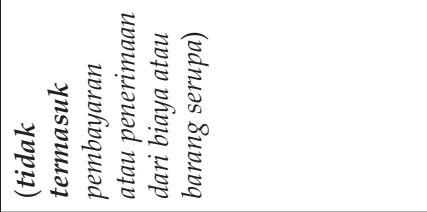 } & 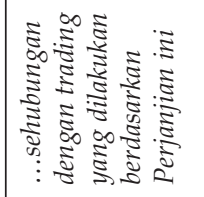 & 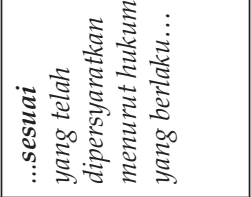 & \\
\hline \multicolumn{2}{|l|}{ 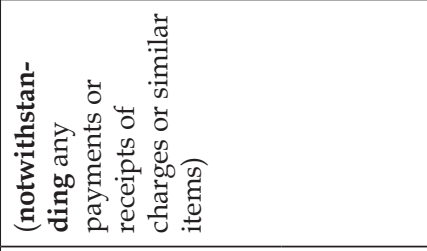 } & 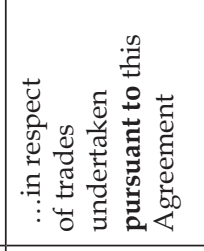 & 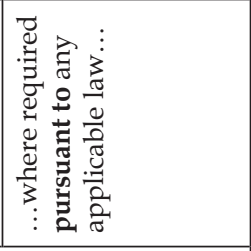 & \\
\hline \multicolumn{2}{|c|}{ 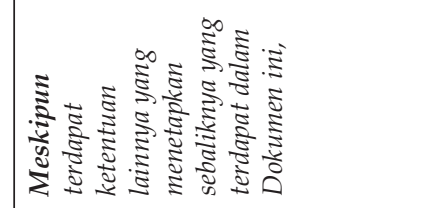 } & \multicolumn{2}{|l|}{ 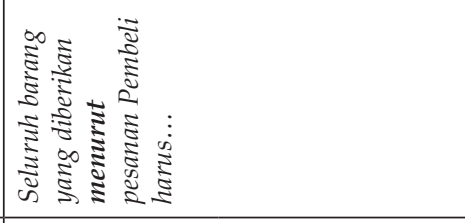 } & 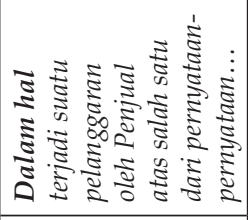 \\
\hline \multicolumn{2}{|l|}{ 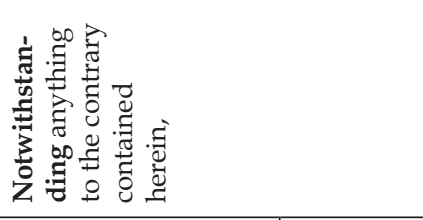 } & \multicolumn{2}{|l|}{ 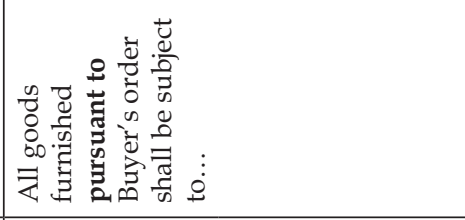 } & 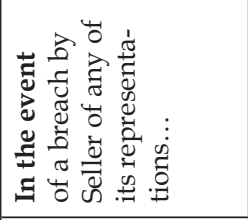 \\
\hline 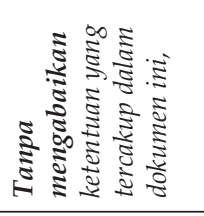 & 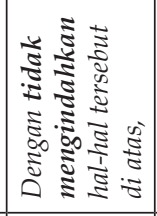 & \multicolumn{2}{|l|}{ 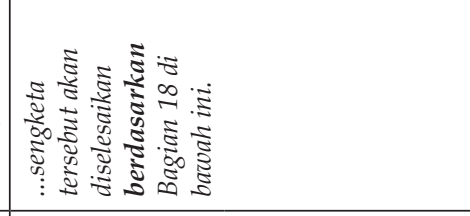 } & 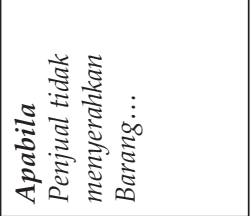 \\
\hline 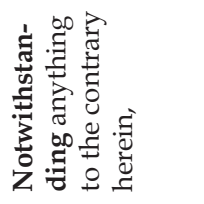 & 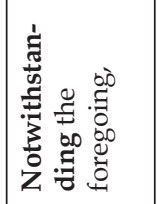 & \multicolumn{2}{|l|}{ 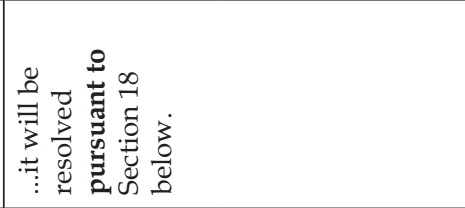 } & 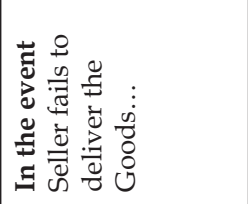 \\
\hline \multicolumn{2}{|l|}{ 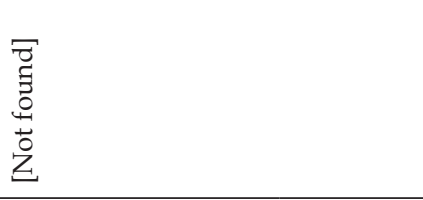 } & 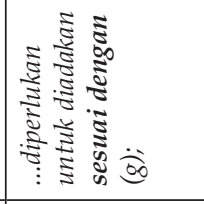 & 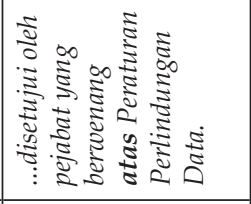 & 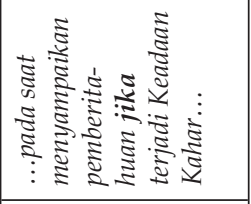 \\
\hline \multicolumn{2}{|l|}{ 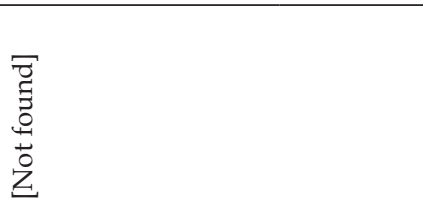 } & 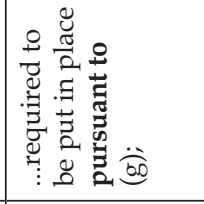 & 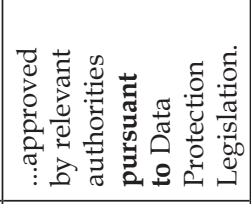 & 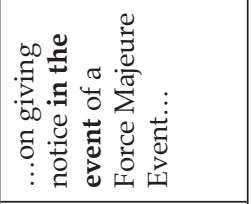 \\
\hline \multicolumn{2}{|l|}{ 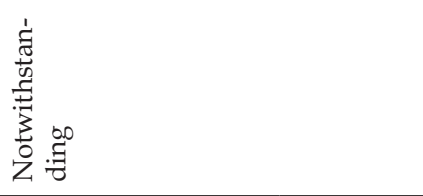 } & 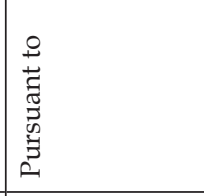 & & 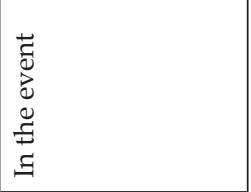 \\
\hline \multicolumn{2}{|l|}{ 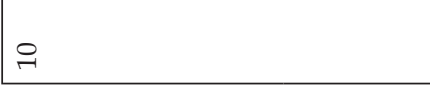 } & \multicolumn{2}{|l|}{$F$} & $\approx$ \\
\hline
\end{tabular}




\begin{tabular}{|c|c|}
\hline \multicolumn{2}{|l|}{ 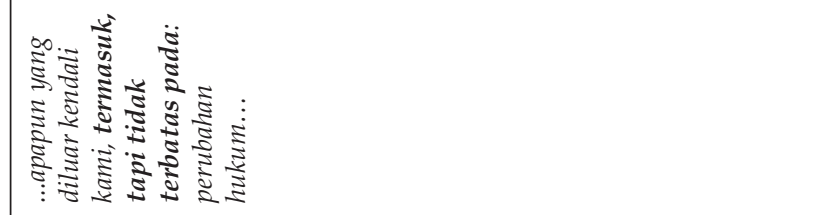 } \\
\hline \multicolumn{2}{|l|}{ 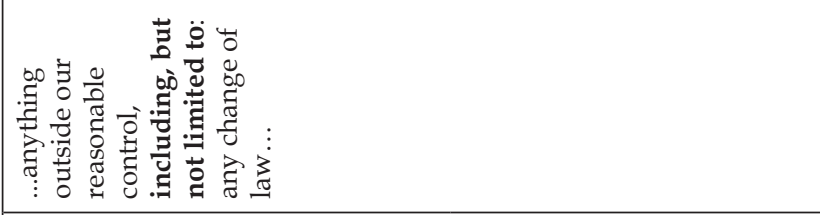 } \\
\hline \multicolumn{2}{|l|}{ 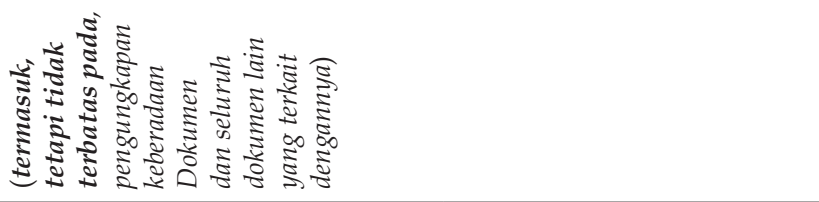 } \\
\hline \multicolumn{2}{|l|}{ 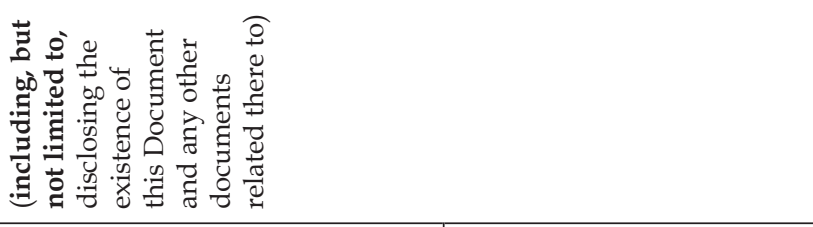 } \\
\hline 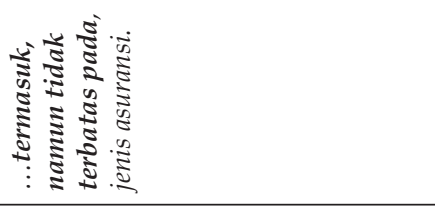 & 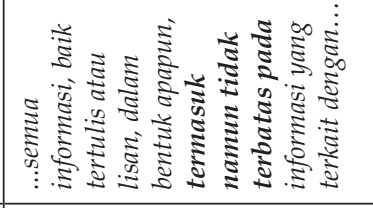 \\
\hline 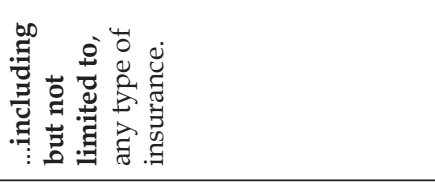 & 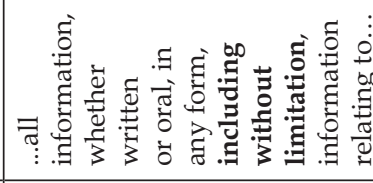 \\
\hline 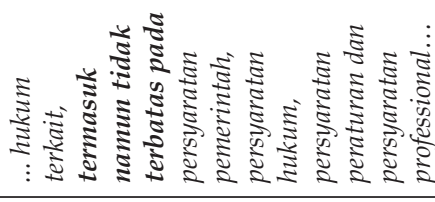 & 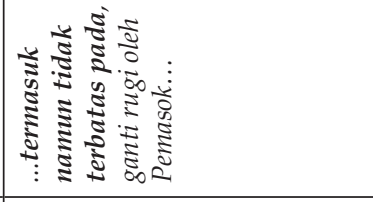 \\
\hline 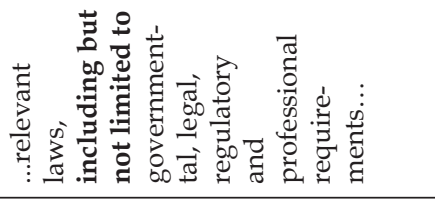 & 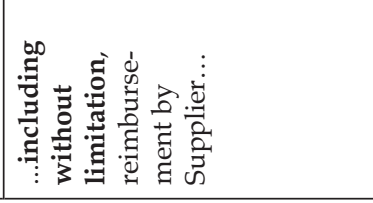 \\
\hline 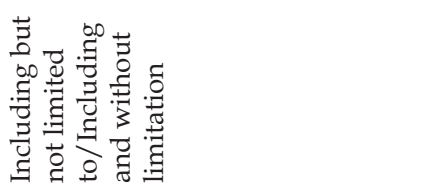 & \\
\hline$\stackrel{9}{\Omega}$ & \\
\hline
\end{tabular}

